\title{
Spinal anaesthesia experience in a patient with progressive supranuclear palsy using MAO-B inhibitor
}

\section{MAO-B İnhibitörü Kullanan Progresif Supranükleer Palsi'li Hastada Spinal Anestezi Deneyimi}

\author{
타이 Toy, @Kenan Kart, @Duygu Taşkın \\ Karabuk University Training and Research Hospital, Deparment of Anesthesiology, Karabük, Turkey \\ Copyright@Author(s) - Available online at www.dergipark.org.tr/tr/pub/medr \\ Content of this journal is licensed under a Creative Commons Attribution-NonCommercial 4.0 International License. CC. NG
}

\begin{abstract}
Progressive supranuclear palsy (PSP) is a rare clinical syndrome characterized by postural instability and mild dementia. The classical clinical picture of PSP includes severe gait and balance disorder, general bradykinesia, frontal dementia, visual disorders, dysarthria and dysphagia. Aspiration pneumonia is the leading cause of death in advanced PSP. We aimed to present our experiences in a 72-year-old patient with PSP using MAO-B inhibitor as an update for anaesthesiologists. We recommend that it should be taken into consideration that patients with PSP have a high risk of aspiration due to dysphagia and use of various medical treatments with high drug interaction and regional anaesthesia should be preferred. At the same time, we recommend the careful use of opioids during general or regional anaesthesia if the drug cannot be discontinued in patients using MAO-B inhibitor.
\end{abstract}

Keywords: Progressive supranuclear palsy, MAO-B inhibitor, anaesthesia

Öz

Progresif supranükleer palsi (PSP), postural instabilite ve hafif demans ile karakterize nadir bir klinik sendromdur. PSP'nin klasik klinik tablosunda şiddetli yürüme ve denge bozukluğu, genel bradikinezi, frontal demans, görme bozuklukları, dizartri ve disfaji vardır. Bu hastalarda disfajinin neden olduğu aspirasyon pnömonisi başlıca ölüm nedenidir.

MAO-B inhibitörü kullanan 72 yaşındaki PSP hastasındaki spinal anestezi deneyimlerimizi sunmayı amaçladık. PSP'li hastalarda disfaji nedeniyle aspirasyon riskinin yüksek olması, ilaç etkileşimi yüksek olan çeşitli medikal tedaviler kullanıyor olmalarının göz önünde bulundurulmasını ve anestezi tercihinin rejyonel anesteziden yana yapılmasını önermekteyiz. Aynı zamanda MAO-B inhibitörü kullanan hastalarda eğer ilaç kesilemiyor ise genel ve rejyonel anestezi sırasında opioidlerin dikkatli kullanılmasını önermekteyiz.

Anahtar Kelimeler : Progresifsupranükleer palsi, MAO-B inhibitörü, anestezi

\section{INTRODUCTION}

Progressive supranuclear palsy (PSP) is a rare clinical syndrome characterized by postural instability and mild dementia. Its mean onset age is 62 , the prevalence is 5-6 people per 100000. Main clinical symptoms are severe gait and balance disorder, general bradykinesia similar to Parkinson's disease, frontal dementia, visual disorders due to vertical gaze palsy, spastic/ataxic dysarthria and dysphagia leading to aspiration. In this picture, especially dysphagia is a very common symptom causing aspiration pneumonia. Aspiration pneumonia is the major cause of death in advanced PSP (1). Anaesthesia management of patients with PSP is important because they use drugs that are likely to interact with anaesthetic and analgesic agents. We aimed to present our experiences in a PSP patient using MAO-B inhibitor as an update for anaesthesiologists. 


\section{CASE REPORT}

An emergency operation due to femur fracture was planned for the 72-year-old female patient who was diagnosed with PSP two years ago. She used rasagilin $1 \mathrm{mg} / \mathrm{day}$ and had no other systemic disease. She had undergone various operations due to nasal fractures, humerus fracture, and radius fracture because of frequent falls. She had balance and gait disorder, vertical gaze restriction, dysarthria and Parkinsonism as PSP symptoms. She did not have any dementia signs. In the airway examination of the patient, Mallampati score was 2, mouth opening and neck movements were sufficient. The patient was taken on the surgery table and monitored: Arterial blood pressure was $120 / 70 \mathrm{mmHg}$, heart rate was $80 / \mathrm{min}$, SpO2 was measured as $97 \%$.

It was decided to apply combined epidural spinal anaesthesia to the patient. After $15 \mathrm{mg}$ hyperbaric bupivacaine was given to subarachnoid space with needle-through-needle method, the epidural catheter was withdrawn due to the intravascular placement and the operation was started with spinal anaesthesia. No sedative agents and opioids were used during the operation. Intermittent oropharyngeal aspiration was performed due to secretion from the rim of the mouth. During the 60-minute-long operation, hemodynamic parameters of the patient were stable. At the end of the operation, she was sent complication-free to the inpatient service. In the service, pain control was provided with intramuscular 75 $\mathrm{mg}$ diclofenac and intravenous $1 \mathrm{gr}$ paracetamol.

\section{DISCUSSION}

Surgery and anaesthesia are planned in a great majority of PSP patients due to various reasons. Anaesthesia management is important in patients with PSP since there is a possibility of difficult airway, the risk of aspiration pneumonia is high and interaction of the drugs they use with anaesthetic agents.

Emergency surgeries may be required due to the injuries caused by imbalance and frequent falls in patients with PSP. These reasons require keeping the information about anaesthesia management up-to-date in patients with PSP. The presented case had a history of several surgeries due to frequent falls. We performed an emergency operation on the patient with femur fracture due to fall.

In patients with PSP, due to the presence of dysphagia and weak sputum excretion, care should be taken to prevent aspiration pneumonia in perioperative management. Patients under general anaesthesia have higher risk of developing postoperative pulmonary complication than regional anaesthesia (2). Preferring regional anaesthesia to general anaesthesia in patients with PSP may reduce the risk of postoperative pulmonary complications, but it does not eliminate the risk completely (3). In the presented case report, general anaesthesia was not preferred in the patient on whom lower extremity surgery was planned; regional anaesthesia was preferred as anaesthesia management. Despite this, it was found that the patient's swallowing function was insufficient and oropharyngeal secretions were aspired intermittently during the operation.

There is no effective treatment that can fully control PSP symptoms. For this reason, levodopa, benzodiazepines, acetyl cholinesterase inhibitors, antidepressants or treatments for the patient's current symptoms may be preferred (4). Rasagiline and other MAO-B inhibitors are also used in PSP patients due to Parkinsonism signs (5). Care should be taken about the interactions of anaesthetic agents that may be used in these patients due to their various drug uses.

A hypermetabolic state may develop with tremor, sweating, fever, hypertension and tachycardia when MAO-B inhibitors and some opioids are used together. It is recommended to discontinue MAO-B inhibitors 2 weeks before surgery due to their interactions with especially high dose fentanyl and pethidine $(6,7)$. There are also studies which report that in non-cardiovascular surgeries, it is safe to give anaesthesia before MAO-B inhibitor is not discontinued in case of avoiding the known drug interactions (8). In this case report, the drugs were not discontinued since an emergency surgery was planned; therefore, opioid use was avoided. Combined spinal epidural anaesthesia was planned to reduce using postoperative opioids; however, epidural catheter was withdrawn due to intravascular location and the operation was completed with spinal anaesthesia. Postoperative analgesia was provided to the patient with non-steroidal anti-inflammatory drugs.

Another issue that should be paid attention is the possibility of difficult airway in patients with PSP. In addition to studies reporting difficult airway due to cervical contracture, there are also studies which report the difficulty of putting on laryngeal airway mask $(9,10)$. Our patient's preoperative assessment did not have any examination finding that predicted difficult airway and cervical extension was not limited. This may be due to the fact that the patient had been diagnosed for 2 years. Since the operation was continued with regional anaesthesia, an apneic condition that required airway control was not experienced. However, it should be kept in mind that airway management might be difficult in patients with PSP.

\section{CONCLUSION}

As a conclusion, we recommend that it should be taken into consideration that patients with PSP have a high risk of aspiration due to dysphagia and use of various medical treatments with high drug interaction and regional anaesthesia should be preferred. At the same time, we recommend the careful use of opioids during general or regional anaesthesia if the drug cannot be discontinued in patients using MAO-B inhibitor.

Financial disclosures: All authors report no financial interests or potential conflicts of interest.

Conflict of Interest: The authors declare that they have no competing interest. 
Informed Consent: The patient's relatives provided their consent for the publication of the content of this report.

\section{REFERENCES}

1. Golbe LI. Progressive supranuclear palsy. Semin Neurol. 2014;34:151-9.

2. Miskovic A, Lumb AB. Postoperative pulmonary complications. Br J Anaesth. 2017;118:317-34.

3. Tonan M, Egi M, Furushima $\mathrm{N}$, et al. A case of spinal anesthesia in a patient with progressive supranuclear palsy. JA Clin Reports. 2018;4:1-3.

4. Lamb R, Rohrer JD, Lees AJ, et al. Progressive supranuclear palsy and corticobasal degeneration: pathophysiology and treatment options. Current Treatment Options Neurol. 2016;18:1-18.

5. $\mathrm{Ng} \mathrm{KP}$, Therriault J, Kang MS, et al. Rasagiline, a monoamine oxidase B inhibitor, reduces in vivo [18F] THK5351 uptake in progressive supranuclear palsy. Neuroimage Clin. 2019;24:102091.
6. Öztürk T, Çıkrıkcı C, Yıldırım F, et al. Kardiyak Cerrahi Geçiren ve Monoamin Oksidaz İnhibitörü Kullanan Parkinson Hastasında Fentanil Reaksiyonu. GKDA Derg. 2014;20:2325.

7. Nakayama H, Matayoshi H. Management of Preoperative Drugs: Psychotropic Drugs. Masui. Japanese J Anesthesiol. 2016;65:1135-43.

8. Krings-Ernst I, Ulrich S, Adli M. Antidepressant treatment with MAO-inhibitors during general and regional anesthesia: a review and case report of spinal anesthesia for lower extremity surgery without discontinuation of tranylcypromine. Int J Clin Pharmacol Ther. 2013;51;76370.

9. Sakai K, Sumikawa K. Anesthetic management of a patient with progressive supranuclear palsy. J Anesthesia. 2006;20:312-3.

10. Maggi G, Schiraldi R, Brogly N, et al. Successful airway management of a patient with progressive supranuclear palsy during the induction of anesthesia. Acta Anaesthesiologica Taiwanica. 2012;2:87-8. 